\title{
Клініко-патогенетичне значення білка теплового шоку при гніздовій алопеції
}

І. М. Сербіна

Харківська медична академія післядипломної освіти

\begin{abstract}
Резюме
Білок теплового шоку 70 (БТШ-70) виступає учасником патогенезу цілої низки автоімунних захворювань. У зв'язку з відсутністю однозначних даних про імунопатологічні процеси, пошуком нових маркерів запалення метою дослідження стала оцінка вмісту БТШ-70 у хворих на гніздову алопецію (ГА) залежно від тяжкості, активності й тривалості захворювання.

Матеріали та методи дослідження. Під спостереженням перебувало 68 пацієнтів з різними формами ГА. Контрольну групу становили 35 здорових осіб. Оцінена ступінь тяжкості та стадія патологічного процесу. Вміст БТШ-70 (нг/мл) визначався в сироватці крові методом твердофазного імуноферментного аналізу.

Результати. Рівень БТШ-70 у хворих на ГА був достовірно підвищеним порівняно з даними, отриманими в контрольній групі. Виявлено залежність між вмістом БТШ-70 і ступенем тяжкості дерматозу, що проявлялось збільшенням показника при всіх варіантах перебігу, особливо в тяжку стадію хвороби - в 1,9 раза відносно групи контролю. У пацієнтів з ознаками прогресування дерматозу секреція БТШ-70 підвищувалася в 2,2 раза порівняно з показником хворих при неактивних проявах ГА. Найбільш виражені порушення досліджуваного показника виявлено в пацієнтів з ознаками активності й тяжким ступенем перебігу ГА. Встановлено збільшення значення БТШ-70 в усі періоди захворювання, але найвищий рівень - у пацієнтів з тривалістю хвороби до 1 року. Показано, що посилення секреції БТШ-70 ( 2 = 66,2\%) підвищує ймовірність розвитку ГА.

Висновки. Виявлені порушення можуть створювати умови для розвитку автоімунного запалення і свідчити про безпосереднє залучення БТШ-70 в механізми формування ГА.

Ключові слова: гніздова алопеція, патогенез, білок теплового шоку 70.
\end{abstract}

DOI: 10.33743/ 2308-1066-2019-3-15-18

\section{Вступ}

Білки теплового шоку (БТШ) являють собою одну з різноманітних молекулярних систем, які захищають клітини від різних цитотоксичних чинників. Аналіз даних, отриманих останнім часом, показав, що позаклітинний білок теплового шоку 70 (БТШ-70) має множинні функції, найважливіша з яких - імуномодуляторна [1, 2]. У процесі імунної відповіді цитокіни індукують експресію БТШ-70, яким відводиться важлива роль у розпізнаванні антигенів і внутрішньоклітинній адгезіі. У нормі БТШ-70 міститься переважно всередині клітини, завдяки чому до нього розвивається імунологічна толерантність. Саме ця властивість є причиною участі БТШ-70 у патогенезі автоімунних захворювань. Будь-яке, в тому числі автоімунне, пошкодження тканин призводить до викиду БТШ-70 у позаклітинний простір, що стимулює макрофаги й дендритні клітини, в результаті чого посилюється синтез адгезивних молекул, прозапальних цитокінів [4, 10].

Безліч досліджень останнім часом присвячено пошуку маркерів активності запального процесу, ризику розвитку захворювань з метою більш точної та ранньої діагностики [3, 5, 14]. Участь БТШ-70 у патогенезі автоімунних захворювань уявляється складним і багаторівневим процесом, що визначається множинними його функціями у внутрішньоклітинних і позаклітинних комунікаціях [13, 15, 17, 19].
В основі механізмів розвитку гніздової алопеції (ГА) лежать клітинно-опосередковані імунні реакції, пов’язані з Т-лімфоцитами і змінами цитокінового профілю, обумовлені генетичними факторами та екзогенними тригерами, що призводить до формування неспецифічного автоімунного запалення в умовах порушення імунної толерантності волосяного фолікула [8, 9]. У ході аналізу наукової літератури було знайдено лише поодинокі зарубіжні роботи останніх років з вивчення БТШ-70 при ГА $[11,16]$. У зв'язку з цим метою дослідження стала оцінка вмісту БТШ-70 (нг/мл) у хворих на ГА залежно від ступеня тяжкості, активності та тривалості захворювання.

\section{Матеріали та методи дослідження}

Під спостереженням перебувало 68 пацієнтів з діагнозом ГА (чоловіків - 32, жінок - 36, віком 18-60 років, середній вік $-28,2 \pm 0,6$ року). В обстежених виявлено різні клінічні форми ГА: осередкова, офіазис, багатоосередкова, дифузна, тотальна (ТА) і універсальна алопеція (УА). Контрольну групу становили 35 здорових осіб відповідної статі та віку.

У всіх пацієнтів був зібраний детальний анамнез захворювання, оцінювалася супутня патологія. Дебют ГА варіював у широких вікових межах - від 2 до 42 років. Середній вік початку патологічного процесу становив 14,8; тривалість захворювання - від 2 тиж 
до 10 років. При цьому кількість попередніх рецидивів захворювання варіювала від 1 до 10, у 32,4\% пацієнтів було більше ніж 2 епізоди ГА. Обтяжений сімейний анамнез щодо ГА відзначено у 18 пацієнтів.

Дослідження проводили після підписання пацієнтом інформованої згоди відповідно до положення, що регулює медичні дослідження. Діагноз встановлювали на підставі клінічної картини і даних інструментально-діагностичного обстеження. Методи клініко-лабораторної діагностики відповідали єдиному плану, який передбачав загальний огляд хворого, загальноприйняті лабораторні аналізи (загальний аналіз крові, загальний аналіз сечі, біохімічний аналіз крові), за показаннями - дослідження щитоподібної залози, консультація суміжних спеціалістів, біопсія шкіри скальпа. Дерматотрихоскопічне дослідження проводили за допомогою комп'ютерно-діагностичної програми та відеодерматоскопічного обладнання Aramo SG (Південна Корея), що включало визначення основних дерматоскопічних ознак ГА (жовті точки, чорні точки, дистрофічне волосся у формі знака оклику, велюс) [12]. Оцінка ступеня тяжкості захворювання проводилася відповідно до шкали SBN, рекомендованої міжнародною групою експертів для оцінки поширеності втрати волосся і ураження нігтів при ГА [7].

Вміст БТШ-70 визначався в сироватці крові методом твердофазного імуноферментного аналізу з використанням комерційного набору BCM Diagnostics (США). Статистична обробка результатів проводилася з використанням програми Microsoft Excel. Застосовували методи описової статистики з розрахунком середньої арифметичної (M), помилки середньої арифметичної $(\mathrm{m})$, середнього квадратичного відхилення $(\sigma)$. Ступінь достовірності відмінності показників визначався за допомогою t-критерію Стьюдента. Аналіз кореляцій у парах показників виконувався за допомогою критерію Спірмена. Аналіз впливу фактора на розвиток алопеції виконувався за допомогою однофакторного дисперсійного аналізу отриманих лінійних моделей. Статистичні розрахунки виконували за допомогою мови R версії v3.2.0.

\section{Результати та їх обговорення}

За клінічними формами, з урахуванням критеріїв вимірювання показників тяжкості, хворі на ГА розподілялися наступним чином: легкий ступінь тяжкості (менше 25\%): S1 - 30 пацієнтів; середній ступінь тяжкості: S2S4a - 20 осіб (S2 (25-49\% втрати волосся) - 7, S3 (5074\% втрати волосся) - 7, S4a (75-95\% втрати волосся) 6); тяжкий ступінь тяжкості: S4b-S5 -18 пацієнтів (S4b (втрата волосся - 96-99\%) - 10; S5 (100\% відсутність волосся на волосистій частині голови і 100\% відсутність волосся на голові, обличчі та тулубі -8 осіб). Зміни нігтьових пластинок за типом поздовжньої смугастості, точкових втиснень і інших типів оніходистрофії спостерігали в 15 пацієнтів.

3 активною стадією патологічного процесу спостерігали 38 пацієнтів, 3 них легкий ступінь тяжкості відзначено у 18, середній і тяжкий - у 12 і 8 хворих відповідно. Хронічну стадію захворювання діагностували в 30 пацієнтів, серед яких легкий ступінь ГА зустрічався у 12 , середній - у 8 і тяжкий - у 10 хворих.

При дерматотрихоскопічному дослідженні кількість жовтих точок не корелювала з активністю патологічного процесу і достовірно не відрізнялась як при активній $(22,5 \pm 5,6)$, так і хронічній стадії ГА $(17,9 \pm 5,1)$. Дистрофічне волосся у вигляді знака оклику $(5,3 \pm 0,4)$ і чорні точки $(6,7 \pm 0,5)$ виявляли тільки в разі активності патологічного процесу. Велюсне волосся, навпаки, було відсутнім у хворих з прогресуючим перебігом дерматозу і з'являлося в незначній кількості у хронічну стадію $(4,7 \pm 0,4)$.

Як показали дослідження, рівень БТШ-70 у сироватці крові хворих на ГА $([0,334 \pm 0,064]$ нг $/$ мл; р < 0,05) був підвищеним порівняно з даними, отриманими в контрольній групі ([0,198 \pm 0,061] нг/мл). Виявлено достовірну залежність між вмістом БТШ-70 і ступенем тяжкості дерматозу - відбувалося збільшення показника при всіх варіантах перебігу ( $<0,05)$, особливо в тяжку стадію хвороби ([0,388 $\pm 0,073]$ нг/мл), р <0,01), відносно рівня у здорових осіб. У пацієнтів, які мали ознаки прогресування дерматозу, значно підвищувалася секреція БТШ-70 ([0,448 $\pm 0,076]$ нг/мл, $\mathrm{p}<0,01)$ порівняно з показником хворих при неактивних проявах ГА $([0,216 \pm 0,052]$ нг/мл), коли його рівень не відрізнявся від референтних значень $(\mathrm{p}>0,05)$.

Аналіз динаміки рівня БТШ-70 залежно від ступеня тяжкості та стадії патологічного процесу при ГА виявив більш виражені порушення (див. рисунок). Так, при активних проявах захворювання значення БТШ-70 достовірно підвищувалося у пацієнтів із середнім ([0,476 \pm $0,074]$ нг/мл, $\mathrm{p}<0,05)$ і тяжким $([0,510 \pm 0,085]$ пг/мл, $\mathrm{p}<0,05)$ ступенями тяжкості в 2,4 та 2,6 раза відповідно, але достовірно не відрізнялися між собою у хворих з різним перебігом. У хронічну стадію при тяжкому $([0,267 \pm 0,065]$ нг $/$ мл, $\mathrm{p}<0,05)$ ступені ГА рівень БТШ-70 був вищим у 1,4 раза, ніж у групі контролю, та в 1,9 раза нижчим за його вміст при активних проявах хвороби. При легкому ступені тяжкості рівень показника в активну стадію захворювання перевищував ([0,342 $\pm 0,071]$ нг $/$ мл, p < 0,05) у 1,7 раза значення у здорових осіб і в 1,4 раза зменшувався відносно вмісту при тяжкому перебігу ГА. При неактивному процесі у хворих легкого та середнього ступенів рівень БТШ-70 не відрізнявся від референтного значення $(\mathrm{p}>0,05)$.

Проводилось дослідження вмісту БТШ-70 залежно від тривалості ГА: до 1 року, від 1 до 3 років та понад 3 років. Виявлено збільшення значення БТШ-70 в усі періоди захворювання ( $<0,05)$, найвищим рівень відзначався у пацієнтів з тривалістю хвороби до 1 року ( [0,362 $\pm 0,088]$ нг $/$ мл, р < 0,05).

Кореляційний аналіз зв'язку між експресією БТШ-70 і перебігом ГА показав, що вихідна величина показника достовірно пов'язана з віком початку

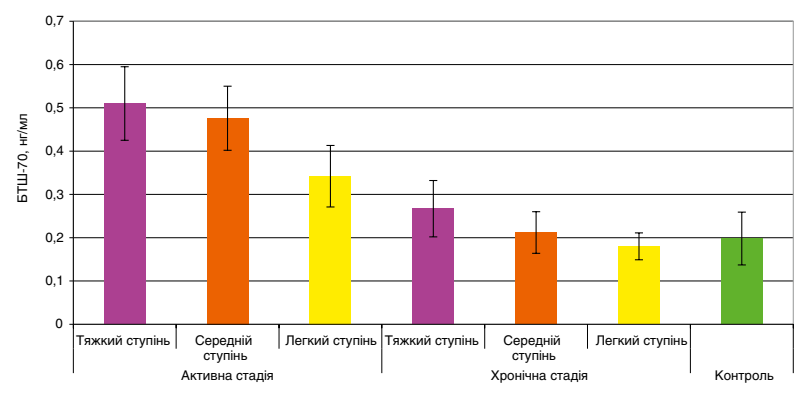

Рисунок. Показник рівня БТШ-70 у хворих на ГА легкого, середнього та тяжкого ступеня тяжкості в активну і хронічну стадію 
захворювання ( $\mathrm{r}=-0,56, \mathrm{p}=0,047)$, активністю $(\mathrm{r}=$ $0,74, \mathrm{p}<0,05)$ і ступенем тяжкості $(\mathrm{r}=0,69, \mathrm{p}<0,05)$. Аналіз впливу БТШ-70 на розвиток ГА за допомогою однофакторної лінійної регресії встановив, що показник має статистично значимий вплив на випадіння волосся. Збільшення секреції БТШ-70 (ๆ2=66,2\%) підвищує ймовірність розвитку ГА $(\mathrm{p}<0,05)$.

Виявлений дисбаланс вмісту сироваткового БТШ-70 у 82,2\% хворих свідчить про безпосереднє залучення його в механізми формування ГА. Проведені дослідження дали змогу показати як загальні закономірності, так і особливості функціонування БТШ-70 при дерматозі. Необхідно відзначити найбільш значущі порушення досліджуваного показника в пацієнтів, які мали ознаки активності і тяжкий ступінь перебігу ГА.

Відомо, що БТШ-70 має різні регуляторні функції (протизапальну, антиапоптотичну), чинить стимулювальний вплив на фактори вродженого імунітету, діючи як «сигнал небезпеки» для організму [1, 4]. Рівень його продукції сильно зростає під дією різних стресових факторів, забезпечуючи репаративні внутрішньоклітинні процеси і виконуючи при цьому функцію молекулярних шаперонів [3]. Порушення ланки захисних механізмів не може не позначатись на функціональній активності клітин організму. В літературі описано активуючі ефекти цього білка на макрофаги, дендритні клітини, Т-лімфоцити. БТШ-70 здатен підсилювати цитотоксичність і проліферацію натуральних кілерів, а також спричиняти позитивний хемотаксис NK-клітин [2]. Показано важливу роль БТШ-70 у механізмах антигенної та перехресної презентації, розвитку автоімунних процесів. БТШ-70 може виступати як протективним, так і предикторним маркером при вітиліго, ревматоїдному артриті та ін. [10, 17, 19].

Цитокіни в даний час розглядають як медіаторну ланку в формуванні патофізіологічної стадії автоімунних реакцій

\section{Список літератури}

1. Евдонин А.Л., Медведева Н.Д. Внеклеточный белок теплового шока 70 и его функции. Цитология. 2009. Т. 51, № 2. С. 130-137.

2. Ивашкин В.Т., Драпкина О.М. Клиническое

3. Кабалык М.А. Клинико-патогенетическое значение белков теплового шока с массой

70 и 27 кДа при остеоартрите. Научно-практическая ревматология. 2017. Т. 55, № 2. С. 187-191. 4. Понасенко О.А., Ганковская Л.В., Свитич О.А. Роль белка теплового шока 70 в патогенезе сердечно-сосудистой патологии. Медицинская иммунология. 2019. Т. 21, № 2. С. 201-208. 5. Яковенко Л.Ф., Ромащенко О.В., Крупская И.В. Белки теплового шока в диагностике и прогнозировании нарушений репродуктивной функции у женщин. Здоровье женщины. 2018. № 7 (133). C. $77-83$.

6. A central role for inducible heat-shock protein 70 in autoimmune vitiligo / J.A. Mosenson, J.M. Eby, C. Hernandez, I.C. Le Poole. Exp Dermatol. 2013. Vol. 22, Iss. 9. P. 566-569.

7. Alopecia areata investigational assessment guidelinese. Part II /E. Olsen, M. Hordinsky, V. Price et al. J. Am. Acad. Dermatol. 2004. Vol. 51. P. 440-447.

8. Alopecia areata is characterized by expansion of circulating Th2/Tc2/Th22, within the skin-homing and systemic T-cell populations / T. Czarnowicki, H.Y. He, H.C. Wen et al. Allergy. 2018. Vol. 73, Iss. 3. P. 713-723.

9. An integrated model of alopecia areata biomarkers highlights both $\mathrm{TH} 1$ and $\mathrm{TH} 2$ upregulaion /T. Song, A.B. Pavel, H.C. Wen et al. J Allergy Clin Immunol. 2018. Vol. 142, Iss. 5. P. 1631-1634 10. Analysis of serum heat shock protein 70 conncentration for diagnosis and disease activity monitoring in patients with rheumatoid arthritis / S.R. Najafizadeh, Z. Ghazizadeh, A.A. Nargesi et al. Cell Stress and Chaperones. 2015. Vol. 20, Iss. 3. P. 537-543.

11. Association of HSPA1B SNP rs6457452 with Alopecia Areata in the Korean population/H. Seok, H.S. Jeon, H.J. Park et al. Immunol. Invest. 2013. Vol. 43, Iss. 3. P. 452-465.

12. Atlas of Trichoscopy: Dermoscopy in Hair and Scalp Disease / L. Rudnicka, M. Olszewska, A. Rakowska, E. Kowalska-Oledzka. Springer Verlag, 2012.507 p.

13. Biomarkers of alopecia areata disease activity and response to corticosteroid treatment / J. Fuentes-Duculan, N. Gulati, K.M. Bonifacio et al. Exp Dermatol. 2016. Vol. 25, Iss. 4. P. 282-286. 14. HSP70: therapeutic potential in acute and chronic cardiac disease settings / B.C. Bernardo, K.L. Weeks, N.L. Patterson, J.R. McMullen. Future Med. Chem. 2016. Vol. 8, Iss. 18. P. 2177-2183. 15. Increased serum HSP70 levels are associated with the duration of diabetes / M. Nakhjavani, A. Morteza, L. Khajeali et al. Cell Stress and Chaperones. 2010. Vol. 15, Iss. 6. P. 959-964.

16. Prevention and treatment of alopecia areata with quercetin in the $\mathrm{C} 3 \mathrm{H} / \mathrm{HeJ}$ mouse model / T.C. Wikramanayake, A.C. Villasante, L.M. Mauro et al. Cell Stress and Chaperones. 2012. Vol. 17. P. $267-274$.

17. Rashighi M., Harris J.E. Vitiligo pathogenesis and emerging treatment. Dermatol Clin. 2017. Vol. 35, Iss. 2. P. 257-265

18. Rork J.F., Rashighi M., Harris J.E. Understanding autoimmunity of vitiligo and alopecia areata. Curr Opin Pediatr. 2016. Vol. 28, Iss. 4. P. 463-469.

19. Samborski P., Grzymislawski M. The role of HSP70 in the the Pathogenesis and Treatment of Inflammatory Bowel Diseases. Adv Clin Exp Med. 2014. Vol. 24, Iss. 3. P. 525-530. при ГА, порушуючи механізми підтримки стану імунотолерантності структур волосяного фолікула [8]. У патогенезі захворювання провідне місце відводиться активації Т-лімфоцитів за Th-1 типом з наступним синтезом прозапальних цитокінів - інтерлейкіну-2 (IL-2), IL-15, інтерферону- $\gamma$ (INF- $\gamma$ ), фактора некрозу пухлин- $\alpha$ (TNF- $\alpha$ ) та ін. Генетичні дослідження та аналіз експресії генів людини показали значимість порушень NKGD-активуючого ліганду і природного рецептора цитотоксичності NKG2D для розвитку ГА $[9,13]$.

Активація БТШ-70 при ГА може запускати сигнальний каскад, що призводить до синтезу адгезивних молекул, прозапальних цитокінів. Підвищений рівень БТШ-70 здатний активувати передачу стрес-асоційованих сигналів NK-клітин, експресія ліганд-рецепторів яких NKG2D виявлена у фолікулярному епітелії волосяного фолікула при ГА, при цьому регулюючи імунний нагляд клітин. У результаті цього відбувається стимуляція молекул МНС класу 1, презентація фолікулярних автоантигенів CD8土-клітин і втрати імунологічної толерантності $[8,18]$. Наявність кореляційних зв’язків підтверджує можливість розгляду БТШ-70 як маркера запального процесу при ГА.

Таким чином, порушення вмісту БТШ-70 свідчить про безпосереднє залучення його в механізми формування ГА. Виявлені розлади у вигляді збільшення рівня БТШ-70 значною мірою корелюють 3 проявами дерматозу - активністю та ступенем тяжкості. Значення БТШ-70 не обмежується лише роллю маркера пошкодження тканин та імунозапального процесу при ГА, а є частиною універсального цитопротективного механізму. 3 огляду на важливу роль БТШ-70 при багатьох патологічних станах, ідентифікація БТШ-керованих шляхів імунної сигналізації є перспективним напрямом у вивченні патогенезу ГА для розробки таргетних методів терапії.

\section{References}

1. Evdonin AL, Medvedeva ND. Vnekletochnyiy belok teplovogo shoka 70 i ego funktsii [Extracellular heat shock protein 70 and its functions]. Tsitologiya. 2009;51(2):130-137.

2. Ivashkin VT, Drapkina OM. Klinicheskoe znachenie oksida azota i belkov teplovogo shoka [The clinical significance of nitric oxide and heat shock proteins]. 2-e izdanie. M.: GEOTAR Media; 2011. $376 \mathrm{p}$.

3. Kabalyik MA. Kliniko-patogeneticheskoe znachenie belkov teplovogo shoka s massoy $70 i 27 \mathrm{kDa}$ pri osteoartrite [Clinical and pathogenetic significance of heat shock proteins with a mass of 70 and $27 \mathrm{kDa}$ in osteoarthritis]. Nauchno-prakticheskaya revmatologiya. 2017;55(2):187-191.

4. Ponasenko OA, Gankovskaya LV, Svitich OA. Rol belka teplovogo shoka 70 v patogeneze serdechno-sosudistoy patologii [The role of heat shock protein 70 in the pathogenesis of cardiovascular disease]. Meditsinskaya immunologiya. 2019;21(2):201-208.

5. Yakovenko LF, Romaschenko OV, Krupskaya IV. Belki teplovogo shoka v diagnostike i prognozirovanii narusheniy reproduktivnoy funktsii u zhenschin [Heat shock proteins in the diagnosis and prognosis of reproductive disorders in women]. Zdorove zhenschinyi. 2018;7(133):77-83. 6. Mosenson JA, Eby JM, Hernandez C, Le Poole IC. A central role for inducible heat-shock protein 70 in autoimmune vitiligo. Exp Dermatol. 2013;22(9):566-569.

7. Olsen E, Hordinsky M, Price V, et al. Alopecia areata investigational assessment guidelinese. Part II. J. Am. Acad. Dermatol. 2004;51:440-447.

8. Czarnowicki T, He HY, Wen HC, et al. Alopecia areata is characterized by expansion of circulating Th2/Tc2/Th22, within the skin-homing and systemic T-cell populations. Allergy. 2018;73(3):713-723. 9. Song T, Pavel AB, Wen $\mathrm{HC}$, et al. An integrated model of alopecia areata biomarkers highlights both TH1 and TH2 upregulation. J Allergy Clin Immunol. 2018;142(5): 1631-1634.

10. Najafizadeh SR, Ghazizadeh Z, Nargesi AA, et al. Analysis of serum heat shock protein 70 concentration for diagnosis and disease activity monitoring in patients with rheumatoid arthritis Cell Stress and Chaperones. 2015;20(3):537-543.

11. Seok H, Jeon HS, Park HJ, et al. Association of HSPA1B SNP rs6457452 with Alopecia Areata in the Korean population. Immunol. Invest. 2013;43(3):452-465

12. Rudnicka L, Olszewska M, Rakowska A, Kowalska-Oledzka E. Atlas of Trichoscopy: Dermoscopy in Hair and Scalp Disease. Springer Verlag, 2012;507 p.

13. Fuentes-Duculan J, Gulati N, Bonifacio KM, et al. Biomarkers of alopecia areata disease activity and response to corticosteroid treatment. Exp Dermatol. 2016;25(4):282-286.

14. Bernardo BC, Weeks KL, Patterson NL, MCMullen JR. HSP70: therapeutic potential in acute and chronic cardiac disease settings. Future Med. Chem. 2016;8(18):2177-2183.

15. Nakhjavani M, Morteza A, Khajeali L, et al. Increased serum HSP70 levels are associated with the duration of diabetes. Cell Stress and Chaperones. 2010;15(6):959-964.

16. Wikramanayake TC, Villasante AC, Mauro LM, et al. Prevention and treatment of alopecia areata with quercetin in the C3H/HeJ mouse model. Cell Stress and Chaperones. 2012;17:267-274.

17. Rashighi M, Harris JE. Vitiligo pathogenesis and emerging treatment. Dermatol Clin 2017;35(2):257-265.

18. Rork JF, Rashighi M, Harris JE. Understanding autoimmunity of vitiligo and alopecia areata. Curr Opin Pediatr. 2016;28(4):463-469.

19. Samborski P, Grzymislawski M. The role of HSP70 in the the Pathogenesis and Treatment of Inflammatory Bowel Diseases. Adv Clin Exp Med. 2014;24(3):525-530. 


\title{
КЛИНИКО-ПАТОГЕНЕТИЧЕСКОЕ ЗНАЧЕНИЕ БЕЛКА ТЕПЛОВОГО ШОКА ПРИ ГНЕЗДНОЙ АЛОПЕЦИИ
}

\author{
И.м. Сербина
}

Харьковская медицинская академия последипломного образования

\section{Резюме}

Белок теплового шока 70 (БТШ-70) является участником патогенеза целого ряда аутоиммунных заболеваний. Отсутствие однозначных данных об иммунопатологических процессах, поиск новых маркеров воспаления обосновывают цель работы: оценка содержания БТШ-70 у больных гнездной алопецией (ГА) в зависимости от степени тяжести, активности и длительности заболевания.

Материалы и методы. Под наблюдением находились 68 пациентов с ГА (мужчин - 32, женщин - 36). Контрольную группу составили 35 здоровых лиц. При обследовании определены степень тяжести и стадия патологического процесса. Содержание БТШ-70 (нг/мл) исследовали в сыворотке крови методом твердофазного иммуноферментного анализа.

Результаты. Уровень БТШ-70 у больных ГА достоверно повышался по сравнению с данными, полученными в контрольной группе. Выявлена зависимость между содержанием БТШ-70 и степенью тяжести дерматоза, когда значения показателя увеличивались при всех вариантах течения, особенно в тяжелой стадии болезни - в 1,9 раза относительно группы контроля. У пациентов, которые имели признаки прогрессирования дерматоза, секреция БТШ-70 повышалась в 2,2 раза по сравнению с показателем больных при неактивных проявлениях ГА. Наиболее выраженные нарушения выявлены упациентов, которые имели признаки активности и тяжелую степень тяжести. Значение БТШ-70 увеличивалось во все периоды заболевания, при этом максимально высокое отмечалось у пациентов с продолжительностью болезни до 1 года. Показано, что увеличение секреции БТШ-70 ( 2 = 66,2\%) повышает вероятность развития ГА.

Выводы. Выявленные нарушения могут создавать условия для развития аутоиммунного воспаления и свидетельствовать о непосредственном привлечении БТШ-70 в механизмы формирования ГА.

Ключевые слова: гнездная алопеция, патогенез, белок теплового шока 70.

\section{CLINICAL AND PATHOGENETIC SIGNIFICANCE OF HEAT SHOCK PROTEIN} IN ALOPECIA AREATA

\author{
I.M. Serbina \\ Kharkiv Medical Academy of Postgraduate Education
}

\section{Abstract}

Heat shock protein 70 (HSP-70) performs a variety of functions, serving as a participant in the pathogenesis of a number of autoimmune diseases. Absence of unambiguous data on immunopathological processes, search for new markers of inflammation substantiate.

The objective of the work: to evaluate the content of HSP-70 in patients with alopecia areata (AA), depending on the severity, activity and duration of the disease.

Materials and methods. We observed 68 patients with different forms of AA ( 32 males and 36 females). The control group consisted of 35 healthy individuals. The severity and stage of the pathological process were evaluated.

Results. The content of HSP-70 ( $\mathrm{ng} / \mathrm{ml})$ was determined in blood serum by the method of enzyme-linked immunosorbent assay. The level of HSP-70 in patients with AA was significantly increased compared with the data obtained in the control group. A correlation was found between the content of HSP-70 and the severity of dermatosis, when there was an increase in the value of the indicator in all options of the course of the disease, especially in the severe stage of the disease - 1.9 times higher than in the control group. HSP-70 increased by 2.2 times compared with patients with inactive manifestations of AA. The most pronounced violations of the investigated indicator were found in patients who had signs of activity and a severe degree of AA. An increase in HSP-70 was identified in all periods of the disease, but the highest level was observed in patients with disease duration of up to 1 year. It is established that an increase in the secretion of HSP-70 $(\eta 2=66.2 \%)$ increases the probability of development of AA.

Conclusions. The revealed violations can create conditions for the development of autoimmune inflammation and indicate the direct involvement of HSP-70 in the mechanisms of AA pathogenesis.

Key words: alopecia areata, pathogenesis, heat shock protein 70.

Сведения об авторе:

Сербина Инесса Михайловна - канд. мед. наук, доцент кафедры дерматовенерологии Харьковской медицинской академии последипломного образования. E-mail: serbinaim@gmail.com 